\title{
IMPLEMENTASI PENDIDIKAN BUDI PEKERTI PADA SISWA
}

\author{
Sutrisno, Nurhadi, M. Mansur \\ FKIP Universitas Muhammadiyah Malang, Indonesia \\ Email: sutrisno@gmail.com
}

\begin{abstract}
Character education is an educational process aimed at learners to develop the values, attitudes, and behaviours that emit noble character or noble character. Research with the aim of, (1) To describe the implementation of character education to students at SMPN 5 Malang; (2) To describe the form of school activities in the implementation of character education to students at SMPN 5 Malang; (3) To explain the constraints faced in the implementation of character education to students at SMPN 5 Malang; (4) To explain a solution that is made to overcome the obstacles to implementation of character education to students at SMPN 5 Malang. This study uses qualitative research techniques. Researchers directly involved in collecting information related to their topic. The collection of data obtained by observation techniques, interviewing techniques, and technical documentation. The informant information that needs to be explored is the principal SMPN5 Malang, Student representatives, Islamic Teachers, PPKn Teachers, and class 7, 8, and 9. Then the data were analyzed by descriptive qualitative. The results showed that the implementation of character education to students in Junior High School 5 Malang to implement school culture that prays together, implement $5 \mathrm{~S}$, flag ceremonies and manners of incorporating the materials into every subject. Form of school activities in the field of religion is Imtaq, Khotmil Qur'an, and commemorating religious holidays. Field of self-development and winning personality to hold extracurricular, flag ceremony, student council activities and comply with regulations. And social fields which carry out social service. Constraints on the internal factors that character education lessons were removed, and students are still unstable, external factors are the impact of globalization, parents and children often indulge milieu wrong. The solution is to provide guidance that provide insight, training and supervision, teachers set a good example, providing facilities supporting character education and establish good communication between parents and the school. The conclusion that the implementation of character education to students at SMPN 5 Malang to implement and incorporate the material culture of the school moral and character are integrated into each subject. School events that shape the field of religion, self-development field and superior personality, and social areas. The obstacles are internal factors and external factors. And solutions to overcome these obstacles is to provide guidance, teachers give good example, providing character education support facilities and establish excellent communication between parents and the school.
\end{abstract}

Keywords: Character Education to Students; Implementation,

\section{PENDAHULUAN}

Pendidikan pada hakekatnya suatu kegiatan yang secara sadar dan sengaja, serta penuh tanggung jawab yang dilakukan oleh orang dewasa kepada anak sehingga timbul interaksi dari keduanya agar anak tersebut mencapai kedewasaan yang dicita-citakan dan berlangsung secara terus menerus, Ahmadi (1991:70). Menurut UUD 1945 pasal 31 ayat (3) menyebutkan, bahwa Pemerintah mengusahakan dan menyelenggarakan satu sistem pendidikan nasional, yang meningkatkan keimanan dan ketakwaan serta akhlak mulia dalam rangka mencerdaskan kehidupan bangsa, yang diatur dengan Undang-Undang. Selain itu juga diperkuat pada Pasal 31 ayat (5) menyebutkan, "Pemerintah memajukan ilmu pengetahuan dan teknologi dengan menjunjung tinggi nilai-nilai agama dan persatuan bangsa untuk kemajuan peradaban serta kesejahteraan umat manusia". 
Menurut UU No. 20 Tahun 2003 Tentang Sistem Pendidikan Nasional tentang dasar fungsi dan tujuan pendidikan berdasarkan Pasal 3 dikatakan sebagai berikut : "Pendidikan Nasional berfungsi mengembangkan kemampuan dan membentuk watak serta peradapan bangsa yang bermartabat dalam rangka mencerdaskan kehidupan bangsa, bertujuan untuk berkembangnya potensi peserta didik agar menjadi manusia yang beriman dan bertakwa kepada Tuhan Yang Maha Esa, berakhlak mulia, sehat, berilmu, cakap, kreatif, mandiri, dan menjadi warga negara yang demokratis dan bertanggung jawab".

Menurut Ki Hadjar Dewantara (dalam Elmubarok 2008:2), mengatakan bahwa pendidikan berarti daya upaya untuk memajukan pertumbuhan nilai moral (kekuatan batin, karakter), pikiran (intellect) dan tumbuh anak yang antara satu dan lainnya saling berhubungan agar dapat memajukan kesempurnaan hidup, yakni, kehidupan dan penghidupan anakanak yang kita didik selaras. Pendidikan pada umumnya dan pendidikan budi pekerti pada khususnya merupakan sarana untuk mengadakan perubahan secara mendasar, karena membawa perubahan individu sampai ke akar-akarnya.

Pendidikan budi pekerti merupakan program pengajaran disekolah yang bertujuan mengembangkan watak atau tabiat siswa dengan cara menghayati nilainilai dan keyakinan masyarakat sebagai kekuatan moral dalam hidupnya melalui kejujuran, dapat dipercaya, disiplin, dan kerja sama Banks, (dalam Zuriah 2008: 18). Budi pekerti merupakan nilai-nilai hidup manusia yang sungguh-sungguh dilaksanakan bukan karena sekadar kebiasaan, tetapi berdasar pemahaman dan kesadaran diri untuk menjadi baik.

Budi pekerti di dapat melalui proses internalisasi dari apa yang ia ketahui, yang membutuhkan waktu sehingga terbentuklah pekerti yang baik dalam umat manusia. Sedangkan menurut Adisusilo (2012 : 191) pendidikan budi pekerti adalah penanaman nilai-nilai tertentu dalam diri siswa, pengajaran nya bertitik tolak dari nilai-nilai sosial tertentu, yakni nilai-nilai pancasila dan nilai-nilai luhur budaya bangsa Indonesia lainnya, yang tumbuh dan berkembang dalam masyarakat Indonesia.

Tujuan pendidikan budi pekerti menurut Cahyoto, (dalam Zuriah 2008 :65) dapat dikembalikan kepada harapan masyarakat terhadap sekolah yang menghendaki siswa memiliki kemampuan dan kecakapan berpikir, menjadi anggota masyarakat yang bermanfaat dan memiliki kemampuan yang terpuji sebagai anggota masyarakat. Bagi sekolah harapan masyarakat mengenai tujuan pendidikan itu tercantum dalam kurikulum yang selanjutnya digunakan sebagai pedoman oleh guru untuk tujuan pelajaran.

Implementasi pendidikan budi pekerti di sekolah dapat membangun etika kemampuan bersosialisasi, dan meningkatkan kemampuan akademik siswa. Pendidikan budi pekerti meliputi emosi, intelektual dan kualitas moral seseorang atau sekelompok orang dalam berperilaku. Pendidikan budi pekerti berhubungan dengan kejujuran, keadilan dan sportifitas, dapat dipercaya, tanggung jawab, respek, sampai dengan memahami perbedaan antar individu dan kelompok. Pengembangan karakter melalui pendidikan budi pekerti memiliki esensi pengembangan nilai-nilai moral, penyelesaian masalah (problem solving) dan ketrampilan interpersonal, etika dalam bekerja, empati, serta refleksi diri.

Pendidikan budi pekerti di Sekolah, banyak kembali diperbincangkan dalam pembentukan kembali moral bangsa sehingga seolah-olah budi pekerti merupakan solusi baru bagi pendidikan bangsa yang mulai terdegradasi secara moral. MenurutAzra (dalam Zuriah 2008 : 111-112), merebaknya tuntutan dan gagasan tentang pentingnya pendidikan budi pekerti di lingkungan 
persekolahan, haruslah diakui berkaitan erat dengan semakin berkembangnya pandangan dalam masyarakat luas bahwa pendidikan nasional dalam berbagai jenjang, khususnya jenjang menengah dan tinggi, telah gagal dalam membentuk peserta didik yang memiliki akhlak, moral, dan budi pekerti yang baik. Lebih jauh lagi, banyak peserta didik sering dinilai tidak hanya kurang memiliki kesantunan baik disekolah, di rumah, dan lingkungan masyarakat, tetapi juga sering terlibat dalam tindak kekerasan massal.

Kalangan pelajar dan mahasiswa dekadensi moral ini tidak kalah memprihatinkan. Perilaku menabrak etika, moral dan hukum dari yang ringan sampai yang berat masih kerap diperlihatkan oleh pelajar dan mahasiswa. Hal lain yang menggejala di kalangan pelajar dan mahasiswa berbentuk kenakalan". Beberapa di antaranya adalah tawuran antar pelajar dan antar mahasiswa.

Bentuk kenakalan lain yang dilakukan pelajar dan mahasiswa adalah meminum minuman keras, pergaulan bebas dan penyalahgunaan narkoba yang bisa mengakibatkan depresi bahkan terkena HIV/AIDS. Fenomena lain yang mencoreng citra pelajar adalah dan lembaga pendidikan adalah maraknya gang pelajar' dan gang motor'. Perilaku mereka bahkan seringkali menjurus pada tindak kekerasan (bullying) yang meresahkan masyarakat dan bahkan tindakan kriminal seperti pemalakan, penganiayaan, bahkan pembunuhan, http://puskurbuk.net (diakses 25 Januari 2014).

Semua perilaku negatif di kalangan pelajar dan mahasiswa tersebut atas, jelas menunjukkan kerapuhan karakter dan budi pekerti yang cukup parah yang salah satunya disebabkan oleh tidak optimalnya pengembangan karakter dan budi pekerti di lembaga pendidikan di samping karena kondisi lingkungan yang tidak mendukung. Ditambah lagi penanaman budi pekerti disekolah untuk saat ini sudah mengalami kemunduran. Data empiris menunjukkan bahwa para guru sudah merasa enggan menegur anak didik yang berlaku tidak sopan, Zuriah (2008:163).

Menurut Muslich (2011: 172-173) pendidikan yang bernuansakan budi pekerti seperti PPKn dan Agama telah gagal menjalankan misinya. Kegagalan ini disebabkan karena beberapa hal, pertama, pelajaran-pelajaran yang mengembangkan budi pekerti seperti Pendidikan Kewarganegaraan, Pendidikan Agama dan Ilmu pengetahuan sosial dalam pelaksanaan pembelajarannya lebih banyak mengedepankan aspek kognitif, dari pada aspek afektif dan psikomotor. Kedua, subtansi pelajaran itu lebih teoritis tidak heran kalau terdapat kesenjangan yang jelas antara teoritis dan wacana yang di bahas dengan realita sosial yang ada.

Selain itu menurut Azizy (2003:108) penyebab bobroknya budi pekerti dan moralitas bangsa Indonesia diperparah oleh tidak ada tawaran solusi dari semua lembaga, semua ahli, semua pejabat, semua pendidik, dan semua profesi lainnya, hampir semuanya mengedepankan kepentingan pribadi, khususnya berupa tuntutan uang, (seperti kenaikan gaji, tunjangan dan semacamnya).

Oleh karena itu, pendidikan budi pekerti perlu diajarkan agar generasi sekarang dan yang akan datang agar terwujudnya manusia Indonesia yang bermoral, berkarakter, berakhlak mulia dan berbudi pekerti luhur merupakan tujuan dari pembangunan manusia Indonesia yang kemudian diimplementasikan ke dalam tujuan pendidikan nasional.

Pendidikan budi pekerti kurang tepat yang hanya dilaksanakan pada pelajaran Agama dan Kewarganegaraan karena dengan menekankan pendidikan budi pekerti hanya pada dua pelajaran tersebut, maka hanya Guru Agama dan Kewarganegaraan yang bertanggung 
jawab terhadap budi pekerti siswa, dan guru-guru mata pelajaran lain tidak ikut terlibat dalam penanaman budi pekerti. Bahkan pendidikan budi pekerti juga harus ada diluar pelajaran, seperti dalam situasi sekolah ,pergaulan, kegiatan ektrakurikuler dan lain-lain, Zuriah (2008:171).

Berkaitan penjelasan diatas bahwa siswa harus mendapatkan pendidikan budi pekerti disekolah karena pendidikan budi pekerti merupakan gerakan untuk menciptakan sekolah yang mampu membentuk etika, tanggung jawab, dan kepedulian peserta didik dengan cara pemberian contoh dan pengajaran sikap yang dapat diterima secara universal.

SMPN 5 Malang, Ialah salah satu sekolah negeri yang ada di kota Malang,. SMPN 5 Malang mempunyai visi "Mewujudkan sekolah unggul dengan mengembangkan ilmu pengetahuan dan teknologi serta berwawasan lingkungan dengan dilandasi iman dan taqwa". Dengan latar belakang yang di paparkan diatas penulis tertarik untuk melaksanakan penelitian terkait dengan implementasi pendidikan budi pekerti pada siswa yang dituangkan ke dalam skripsi yang berjudul "IMPLEMENTASI PENDIDIKAN BUDI PEKERTI PADA SISWA DI SMPN 5 MALANG"

\section{METODE}

Dalam perspektif pendekatan penelitian penulis menggunakan metode kualitatif menurut Zuriah (2009:92) dalam bukunya metodologi penelitian sosial dan pendidikan yang mengatakan bahwa penelitian kualitatif memerlukan ketajaman analisis, objektifitas, sistematis dan sistemik sehingga diperoleh ketepatan dalam interprestasi, sebab akibat dari suatu fenomena atau gejala bagi penganut penelitian kualitatif adalah totalitas atau Gestalt.

Pendekatan penelitian kualitatif perhatiannya lebih banyak ditujukan pada pembentukan teori substansif berdasarkan konsep-konsep yang timbul dari data empiris. Dalam penilaian kualitatif, peneliti merasa "tidak tahu apa yang tidak diketahui", sehingga desain penelitian yang dikembangkan selalu merupakan kemungkinan yang terbuka akan berbagai perubahan yang diperlukan dan lentur terhadap perubahan yang diperlukan dan lentur terhadap kondisi yang ada di lapangan pengamatan. Penelitian kualitatif adalah prosedur penelitian yang menghasilkan data deskriptif berupa katakata tertulis atau lisan dari orang-orang dan perilaku yang dapat di amati, Moleong (dalam Zuriah 2009:92). Penelitian ini menggunakan pendekatan kualitatif karena : a) lebih mudah mengadakan penyesuaian dengan kenyataan yang berdimensi ganda, b) lebih mudah menyajikan secara langsung hakikat hubungan antara peneliti dan subjek penelitian.

Jenis penelitian yang digunakan adalah penelitian lapangan. Penelitian lapangan dapat di anggap sebagai pendekatan luas dalam penelitian kualitatif atau sebagai metode untuk mengumpulkan data kualitatif. Ide pentingnya adalah bahwa peneliti berangkat ke lapangan untuk mengadakan pengamatan terhadap suatu keadaan alamiah. Pendekatan ini terikat erat dengan pengamatan-pengamatan berprasyarat (Moleong, 2011: 26).

\section{HASIL DAN PEMBAHASAN Implementasi Pendidikan Budi Pekerti Pada Siswa di SMPN 5 Malang}

Pendidikan budi pekerti adalah gerakan untuk menciptakan sekolah yang mampu membentuk etika, tanggung jawab, dan kepedulian peserta didik dengan cara pemberian contoh dan pengajaran sikap yang dapat diterima secara universal. Semua orang dewasa di sekolah menjadi model pendidikan budi pekerti bagi siswa. Secara terus menerus, siswa akan mengamati semua orang dewasa di sekolah 
guru, pengelola, staf, pengelola kantin, sampai dengan bagian kebersihan yang dilihat sebagai contoh model mana yang baik dan mana yang buruk. Setiap guru, baik dalam kegiatan akademik maupun kegiatan ekstrakurikuler. Pendidikan budi pekerti adalah upaya untuk membekali peserta didik melalui kegiatan bimbingan, pengajaran, dan latihan selamapertumbuhan dan perkembangan dirinya sebagai bekal bagi masa depannya, agar memiliki hati nurani yang bersih, berperangai baik, serta menjaga kesusilaan dalam melaksanakan kewajiban terhadap Tuhan dan terhadap sesama makhluk sehingga terbentuk pribadi seutuhnya yang tercermin pada perilaku berupa ucapan, perbuatan, sikap, pikiran, perasaan, kerja dan hasil karya berdasarkan nilai-nilai agama serta norma dan moral luhur bangsa, Muslich (2011: 173-174). Ini terlihat dari pengamatan yang dilakukan peneliti secara kontinyu, bahwa segala suatu yang baik dalam proses belajar mengajar maupun diluar proses pembelajaran dikelas, melalui kegiatankegiatan sekolah dan budaya sekolah dalam menanamkan nilai-nilai budi pekerti.

Berdasarkan wawancara dengan Bapak Kepala sekolah SMPN 5 Malang R.V. Sudharmanto S.Pd. MK.Pd. menegaskan bahwa dalam implementasi pendidikan budi pekerti pada siswa di SMPN 5 Malang sangat penting, masyarakat yang berkarakter dan budi pekerti luhur sangat dibutuhkan. Pendidikan budi pekerti peserta didik dapat dilaksanakan melalui kegiatankegiatan yang dilaksanakan di sekolah dan budaya-budaya yang dikembangkan sekolah. disimpulkan bahwa SMPN 5 Malang telah melaksanakan pendidikan budi pekerti yaitu dengan mengembangkan dan melaksanakan budaya sekolah seperti 5S dalam kehidupan sehari-hari yaitu salam, senyum, sapa, salim dan sopan santun, membudayakan hidup tertib dan mengikuti kegiatan ektrakurikuler untuk mengembangkat bakat siswa. Strategi yang digunakan adalah pembinaan kepada peserta didik secara terus menerus misalnya melaksanakan kegiatan keagamaan seperti sholat berjamaah, kegiatan imtaq setiap hari rabu pagi sebelum pelajaran mulai, melaksanakan kegiatan jumaat bersih ini melatih kerjasama dan gotong royong siswa dan sekolah menyisipkan materi budi pekerti pada mata pelajaran Agama, PPKn dan semua mata pelajaran juga menyisipkan budi pekerti.

Seperti yang sudah dijelaskan tersebut nilai-nilai budi pekerti menurut Depdiknas, (dalam Zuriah 2008;69-70) adalah ada 18 nilai-nilai budi pekerti perilaku dasar dan sikap yang diharapkan dimiliki peserta didik sebagai dasar pembentukan pribadinya. Serta strategi pendidikan budi pekerti menurut Zuriah (2008:80) dilakukan pembinaan dan upaya pembinaan. Berdasarkan hasil wawancara, observasi dan dokumentasi dapat ditarik kesimpulan bahwa seluruh siswa telah mendapatkan pendidikan budi pekerti, contoh nilai-nilai budi pekerti yang dilaksanakan di SMPN 5 Malang adalah para siswa melaksanakan budaya $5 \mathrm{~S}$ yaitu salam, salim, senyum, sapa dan sopan santun yang dimana dalam budaya $5 \mathrm{~S}$ tersebut siswa telah melaksanaan nilai-nilai budi pekerti seperti memiliki tatakrama dan sopan santun, saling menghormati, disiplin diri, dan menumbuhkan cinta dan kasih sayang.

Strategi yang dilakukan sekolah adalah memasukkan materi moral dan budi pekerti ini secara terpadu (integrated) ke dalam setiap mata pelajaran dan memberikan bimbingan yaitu pemahaman kepada siswa apabila sudah paham selanjutnya dilatih dan diawasi. Seperti yang sudah dijelaskan tersebut nilai-nilai budi pekerti menurut Depdiknas, (dalam Zuriah 2008;69-70) adalah ada 18 nilainilai budi pekerti perilaku dasar dan sikap yang diharapkan dimiliki peserta didik sebagai dasar pembentukan pribadinya. 
Serta strategi pendidikan budi pekerti menurut Zuriah (2008 :80) dilakukan pembinaan dan upaya pembinaan.

Berdasarkan hasil wawancara, observasi dan dokumentasi dapat ditarik kesimpulan bahwa seluruh siswa telah mendapatkan pendidikan budi pekerti, contoh nilai-nilai budi pekerti yang dilaksanakan di SMPN 5 Malang adalah para siswa melaksanakan kegiatan upacara setiap hari senin dan hari besar nasional. Dalam kegiatan upacara bendera tersebut siswa telah melaksanaan nilai-nilai budi pekerti seperti memiliki disiplin diri dan memiliki rasa tanggung jawab. Strateginya yang digunakan memasukkan materi moral dan budi pekerti (integrated) ke dalam setiap mata pelajaran, adanya pembinaan kepada seluruh siswa untuk mengikuti kegiatan dan budaya sekolah misalnya upacara bendera secara tidak langsung akan melatih kedisiplinan, cinta tanah air, dan membentuk budi pekerti yang baik kepada anak. Seperti yang sudah dijelaskan tersebut nilai-nilai budi pekerti menurut Depdiknas, (dalam Zuriah 2008;69-70) adalah ada 18 nilai-nilai budi pekerti perilaku dasar dan sikap yang diharapkan dimiliki peserta didik sebagai dasar pembentukan pribadinya. Serta strategi pendidikan budi pekerti menurut Zuriah (2008:80) dilakukan pembinaan dan upaya pembinaan.

Disimpulkan bahwa implementasi pendidikan budi pekerti pada siswa sudah berjalan dengan baik dan lancar, secara keseluruhan perilaku atau kebiasaan siswa sudah mencerminkan nilai-nilai budi pekerti contohnya sopan santun, disiplin, menghormati guru mematuhi tata tertib sekolah, tidak membeda-bedakan teman. Hal ini tidak terlepas dari kebijakan sekolah yang diberikan sekolah tentang implementasi pendidikan budi pekerti pada siswa yang dimana sekolah berkomitmen untuk melaksanakan dan mengajarkan pendidikan budi pekerti.
Berdasarkan hasil wawancara, observasi dan dokumentasi di lapangan, implementasi pendidikan budi pekerti pada siswa serius dilakukan. Terbukti dari berbagai kegiatan sehari-hari maupun kegiatan yang diprogramkan, seperti pelaksanakan sholat berjamaah, sholat merupakan sarana untuk memperbaiki sifat manusia agar menjadi lebih disiplin, dapat mengendalikan diri, lebih tenang, dan terkendali, mencintai kebersamaan, dan senantiasa ingat kepada kepada Allah SWT. Seperti yang sudah dijelaskan tersebut nilai-nilai budi pekerti menurut Depdiknas, (dalam Zuriah 2008;69-70) adalah ada 18 nilai-nilai budi pekerti perilaku dasar dan sikap yang diharapkan dimiliki peserta didik sebagai dasar pembentukan pribadinya. Serta strategi pendidikan budi pekerti menurut Zuriah (2008:80) dilakukan pembinaan dan upaya pembinaan.

\section{Bentuk kegiatan sekolah dalam implementasi pendidikan budi pekerti pada siswa di SMPN 5 Malang}

SMPN 5 Malang merupakan salah satu SMP favorit di kota Malang. Oleh karena itu, telah menjadi keharusan untuk membentuk moral dan budi pekerti yang unggul dan tidak hanya membentuk siswa yang cerdas secara akademik saja. Dalam sekolah ini, pendidikan budi pekerti selain di integrasikan dalam setiap mata pelajaran juga di laksanakan melalui kegiatankegiatan dan budaya sekolah. Menurut Zuriah (2008:171) pendidikan budi pekerti juga harus ada diluar pelajaran, seperti dalam situasi sekolah, pergaulan, kegiatan ekstrakurikuler dan lain-lain. Dengan demikian pelaksanaan pendidikan budi pekerti tidak hanya diintegrasikan pada setiap mata pelajaran tetapi dapat dilaksanakan pada luar mata pelajaran.

Semua program kegiatan sekolah SMPN 5 Malang wajib diikuti oleh semua siswa. Misalnya program kegiatan imtaq 
yang dilakukan pada setiap hari rabu jam pertama yang wajib diikuti seluruh siswa muslim dilaksanakan di kelas yang di pandu oleh guru agama melalui media televisi dan di awasi oleh wali kelasnya masingmasing. Imtaq merupakan pembinaan yang dilandasi keimanan dan ketaqwaan, siswa yang memiliki iman dan takwa yang tinggi pasti memiliki kecerdasan emosional yang tinggi pula jadi wawasan imtaq sangat penting untuk memberikan dasar potensi psikologis seperti inisiatif dan empati, adaptasi, komunikasi dan kerjasama. Sehingga dengan kegiatan imtaq siswa akan meyakini adanya Tuhan Yang Maha Esa dan selalu menaati ajarannya, tumbuhnya disiplin diri, memiliki rasa tanggungjawab, mampu mengendalikan diri, berpikir positif, karena setiap perbuatan manusia akan selalu diawasi oleh Allah SWT. Melalui program kekegiatan sekolah tersebut dapat menciptakan dan mencetak generasi yang unggul dan berbudi pekerti baik.

Berdasarkan hasil wawancara dan dokumentasi, dapat ditarik kesimpulan bahwa program kegiatan sekolah dapat membentuk budi pekerti siswa baik seperti program kegiatan memperingati hari besar agama misalnya memperingati Maulid Nabi Muhammad SAW, peringatan Maulid Nabi tidak hanya mengenang hari kelahiran nabi Muhammad SAW saja tetapi juga mengingat jasa-jasa beliau yang telah menyebarkan agama islam keseluruh dunia serta meneladani sikap dan perilakunya yang penyabar, rendah hati, sopan dalam bertutur kata, jujur, tidak pernah berdusta dan luhur budi pekertinya. Sehingga dengan melaksanakan kegiatan tersebut maka siswa telah berperilaku yang mencerminkan kepatuhan kepada agama, serta dapat menumbuhkan disiplin diri, berpikir positif, penyayang, dan sopan santun sesuai sikap yang dimiliki Nabi Muhammad SAW. Melalui program kegiatan sekolah maka seluruh siswa mendapatkan pendidikan budi pekerti dengan baik.

Berdasarkan hasil wawancara, observasi dan dokumentasi dapat ditarik sebuahkesimpulanbahwadalampelaksanaan program kegiatan sekolah di dalamnya terdapat pelaksanaan pendidikan budi pekerti pada siswa, misalnya ketika sekolah menyelenggarakan kegiatan kepramukaan yang dimana manfaat mengikuti kegiatan kepramukaan akan membentuk karakter yang disiplin dan bertanggang jawab, melatih kemandirian, melatih kepemimpinan, memiliki kebersamaan dan gotong royong, mengembangkan potensi diri karena dalam kegiatan kepramukaan telah diajarkan dan dilatih menjadipribadiyang unggul. Dengan melaksanakan dan mengikuti program kegiatan sekolah akan meningkatkan budi pekerti siswa. kesimpulan bahwa dalam pelaksanaan kegiatan sekolah di dalamnya terdapat pelaksanaan pendidikan budi pekerti pada siswa, program-program yang dibuat dan dilaksanakan sekolah sudah mencerminkan nilai-nilai budi pekerti luhur. Seperti program kegiatan melaksanakan sholat berjamaah, sholat merupakan sarana untuk memperbaiki sifat manusia agar menjadi lebih disiplin, dapat mengendalikan diri, lebih tenang, dan terkendali, mencintai kebersamaan, dan senantiasa ingat kepada kepada Allah SWT. Melalui program kegiatan sekolah maka seluruh siswa mendapatkan pelatihan atau pendidikan budi pekerti dengan baik.

Berdasarkan hasil wawancara, observasi dan dokumentasi dapat diambil kesimpulan bahwa kegiatan sekolah dalam pelaksanaan pendidikan budi pekerti pada siswa misalnya melaksanakan pemilihan ketua OSIS. Karena dengan diselenggarakan pemilihan ketua OSIS maka siswa diberi kesempatan untuk mncalonkan menjadi ketua OSIS dan diberi kesempatan yang sama untuk memilih dan menyalurkan aspirasinya sesuai dengan hati nuraninya masing-masing tanpa ada paksaan dari siapapun serta menghargai 
pendapat orang lain, siswa diajarkan untuk lebih tanggung jawab dan dapat menerima hasil keputusan yang ditetapkan. Itu merupakan perwujudan nilai-nilai budi pekerti yaitu memiliki rasa tanggung jawab yakni sikap dan perilaku seseorang untuk melaksanakan tugas dan kewajiban yang seharusnya dia lakukan terhadap diri sendiri, masyarakat dan Tuhan Yang Maha Esa, memiliki sikap saling menghormati dan menghargai dalam hubungan antar individu dan kelompok berdasarkan norma dan tata cara yang berlaku, mengembangkan potensi diri atau kemampuan sesuai bakat yang dimiliki, dan menumbuhkan sikap disiplin.

\section{Kendala-kendala yang dihadapi dalam imlementasi pendidikan budi pekerti pada siswa di SMPN 5 Malang}

Implementasi pendidikan budi pekerti pada siswa di SMPN 5 Malang dalam pelaksanaannya sudah berjalan sesuai dengan program sekolah. Akan tetapi dalam pelaksanaannya program tersebut tidak terlepas dari faktor penghambat atau kendala-kendala yang terjadi. Faktor penghambat maupun kendala-kendala menjadi faktor tidak maksimalnya dalam pelaksanaan pendidikan budi pekerti pada organisasi siswa intra sekolah tersebut. Dengan demikian peneliti ingin mengetahui apa saja yang menjadi kendala-kendala implementasi pendidikan budi pekerti pada siswa di SMPN 5 Malang. Masalah globalisasi saat ini telah merongrong ideologi pancasila semakin jelas terlihat. Nilai-nilai sosial yang dulunya dijunjung tinggi kini berlahan terkikis oleh kebudayaan asing yang menyebar dengan leluasa sehingga terjadinya kemrosotan moral generasi muda. Sekarang ini tawuran antar pelajar sudah menjadi berita biasa, pornografi dan kekerasan yang terjadi saat ini juga tidak luput dari efek dari globalisasi.
Berdasarkan penjelasan tersebut dapat ditarik kesimpulan bahwa dampak globalisasi merupakan faktor yang menjadi kendala dalam implementasi pendidikan budi pekerti pada organisasi siswa intra sekolah, karena globalisasi telah hadir ditengah-tengah kehidupan siswa serta mempengaruhi sikap dan perbuatan mereka. Kemudian faktor orang tua yang sering memanjakan anak menimbulkan tidak berjalannya pendidikan budi pekerti karena anak yang salah tidak mendapat teguran dari orang tua dan membutuhkan proses yang agak lama untuk pemahaman tentang budi pekerti yang baik kepada anak.

Berdasarkan penjelasan diatas dapat ditarik kesimpulan bahwa kendalakendala dalam implementasi pendidikan budi pekerti pada siswa yaitu usia siswa yang masih menginjak remaja awal sehingga perlu proses yang lama dalam pemahaman nilai-nilai budi pekerti yang baik dan faktor orang tua yang sering memanjakan anak dan selalu membela anak yang berbuat salah, sehingga menjadi kendala dalam pelaksanaan pendidikan budi pekerti pada siswa. Lebih lanjut diterangkan oleh Guru PPKn bahwa faktor yang menjadi kendala dalam implementasi pendidikan budi pekerti pada siswa yaitu dihapuskanya pelajaran pendidikan budi pekerti itu sendiri. Walaupun budi pekerti merupakan bagian dari mata pelajaran agama yang salah satu bahasannya adalah akhlak/budi pekerti, tetapi memperoleh porsi yang amat sangat kecil yaitu dua jam dalam seminggu. Oleh karena itu, sentuhan aspek moral/akhlak/budi pekerti menjadi amat tipis dan tandus. Padahal zaman terus berjalan, budaya terus berkembang.

Berdasarkan hasil wawancara dan observasi diatas, dapat disimpulkan bahwa kendala-kendala dalam implementasi pendidikan budi pekerti pada siswa yaitu akibat dampak globalisasi itu sendiri siswa 
menirukan gaya artis kesukaannya tanpa ada filter dan pengawasan dari orang tua, kurangnya kedisiplinan siswa sehingga siswa berlaku sesuka hatinya, bersikap apatis yaitu apabila tidak diperintah maka siswa itu tetap berdiam diri, lingkungan pergaulan yang salah akan mengakibatkan siswa terjerumus,dan faktor usia siswa yang masih menginjak awal remaja sehingga masih labil. Oleh karena itu implementasi pendidikan budi pekerti pada siswa harus dilaksanakan dengan konsisten dengan dukungan dari semua pihak, baik pihak sekolah guru, karyawan, kepala sekolah dengan orang tua murid dan selalu bersinergis untuk mewujudkan budi pekerti anak yang luhur.

Solusi yang dilakukan untuk mengatasi kendala-kendala implementasi pendidikan budi pekerti pada siswa di SMPN 5 Malang.

Berdasarkan permasalahan yang ada sebagai kendala-kendala implementasi pendidikan budi pekerti pada siswa dari informan, maka peneliti ingin mengetahui bagaimana solusi yang diambil dalam mengatasi kendala-kendala tersebut melalui pendekatan-pendekatan terhadap siswa dan orang tua atau program-program kegiatan sekolah. Implementasi pendidikan budi pekerti di sekolah dapat membangun etika kemampuan bersosialisasi, dan meningkatkan kemampuan akademik siswa. Pendidikan budi pekerti meliputi emosi, intelektual dan kualitas moral seseorang atau sekelompok orang dalam berperilaku. Pendidikan budi pekerti berhubungan dengan kejujuran, keadilan dan sportifitas, dapat dipercaya, tanggungjawab, respek, sampai dengan memahami perbedaan antar individu dan kelompok.

Berdasarkan hasil wawancara, observasi dan dokumentasi dapat disimpulkan bahwa dalam implementasi pendidikan budi pekerti pada siswa tidak hanya diajarkan melalui teori saja akan tetapi diberikan contoh tauladan, sehingga anak akan memiliki budaya malu jika melakukan hal yang kurang baik disekolah seperti yang pertama malu jika datang terlambat atau pulang cepat (harus disiplin), kedua malu karena melihat rekannya sibuk melakukan aktifitas (harus lebih aktif), ketiga malu karena melanggar peraturan(harus mematuhi tata tertib), keempat malu untuk berbuat salah (harus berperilaku yang baik), kelima malu karena bekerja tidak berprestasi (harus lebih rajin lagi), keenam malu karena tugas tidak terlaksana atau tidak selesai(harus lebih bertanggung jawab), ketujuh malu karena tidak tidak berperan aktif dalam mewujudkan kebersihan lingkungan kantor/ sekolah (hurus menjaga kebersihan). Pihak sekolah harus cermat dalam melihat apa saja yang menjadi kendala-kendala dalam implementasi pendidikan budi pekerti pada siswa agar dapat segera memberikan sebuah solusi yang dilaksanakan dalam menyelesaikan permasalahan tersebut.

Untuk itu perlu adanya kerjasama dan kepedulian dari berbagai pihak dalam sekolah maupun luar sekolah untuk melaksanakan pendidikan budi pekerti pada siswa yang sesuai dengan visi dan misi SMPN 5 Malang. Hal ini sesuai dengan yang diamanatkan UU No. 20 Tahun 2003 Tentang Sistem Pendidikan Nasional tentang dasar fungsi dan tujuan pendidikan berdasarkan Pasal 3 dikatakan sebagai berikut: "Pendidikan Nasional berfungsi mengembangkan kemampuan dan membentuk watak serta peradapan bangsa yang bermartabat dalam rangka mencerdaskan kehidupan bangsa, bertujuan untuk berkembangnya potensi peserta didik agar menjadi manusia yang beriman dan bertakwa kepada Tuhan Yang Maha Esa, berakhlak mulia, sehat, berilmu, cakap, kreatif, mandiri, dan menjadi warga negara yang demokratis dan bertanggung jawab".

\section{SIMPULAN}

Berdasarkan pada fokus penelitian, paparan data, dan temuan penelitian 
serta pembahasan tentang "implementasi pendidikan budi pekerti pada siswa di SMP Negeri 5 Malang" maka hasil penelitian ini dapat disimpulkan sebagai berikut : Implementasi pendidikan budi pekerti pada siswa di SMP Negeri 5 Malang terlihat dari berbagai budaya yang dilakukan seharihari maupun kegiatan yang diprogramkan. Misalnya budaya sekolah dengan kegiatan untuk meningkatkan ketakwaan misalnya, sholat fardu berjamaah, sholat jumat berjamaah. Budaya melaksanakan $5 \mathrm{~S}$ salam, sapa, senyum, salim, dan sopan santun. Budaya menumbuhkan sikap gotong royong, tertib, disiplin, menghargai waktu, ramah tamah, jujur, dan saling menyayangi antar warga sekolah. Hal tersebut sudah terlaksana dengan baik sebagai wujud pelaksanaan pendidikan budi pekerti di lingkungan sekolah dan memasukkan materi moral dan budi pekerti ini secara terpadu (integrated) ke dalam setiap mata pelajaran.

Bentuk kegiatan sekolah dalam implementasi pendidikan budi pekerti pada siswa di SMP Negeri 5 Malang yaitu dibidang agama program kegiatannya adalah melaksanakan imtaq pada setiap hari rabu jam pertama, khotmil qur'an dilaksanakan pada minggu ke 4 pada setiap bulan, nuzulul qur'an pada setiap 17 ramadhan, pondhok ramadhan pada bulan ramadhan, melakukan shalat fardhu berjamaah dan shalat jumat disekolah. Dibidang budi pekerti luhur atau akhlak mulia adalah melaksanakan shalat dhuhur berjamaah secara rutin dan shalat jumat secara rutin. Pada bidang kepribadian unggul, wawasan,dan bela negara adalah melaksanakan kegiatan ekstrakurikuler, bakti sosial, penerapan tatatertib sekolah, melaksanakan kegiatan OSIS dan melaksanakan upacara bendera. kegiatan sekolah tersebut terdapat proses pemupukan dan pengembangan budi pekerti dan kepribadian yang baik.
Kendala-kendala yang menjadi penghambat dalam implementasi pendidikan budi pekerti pada siswa di SMP Negeri 5 Malang adalah faktor internal dan faktor eksternal.

Faktor internalnya adalah dihapuskanya pelajaran pendidikan budi pekerti itu sendiri. Walaupun budi pekerti merupakan bagian dari mata pelajaran agama yang salah satu bahasannya adalah akhlak/budi pekerti, tetapi memperoleh porsi yang amat sangat kecil yaitu dua jam dalam seminggu maka sentuhan aspek moral/akhlak/budi pekerti menjadi amat tipis dan tandus. Usia siswa yang masih menginjak remaja awal sehingga masih labil perlu proses yang lama dalam pemahaman nilai-nilai budi pekerti yang baik, sikap apatisnya siswa itu sendiri yaitu apabila tidak diperintah maka siswa itu tetap berdiam diri tidak mau berbuat kebaikan.

Faktor eksternal yang pertama adalah dampak globalisasi merupakan faktor yang menjadi kendala karena globalisasi telah hadir ditengah-tengah kehidupan siswa serta mempengaruhi sikap dan perbuatan mereka banyak siswa yang menirukan gaya artis kesukaan mereka yang mencerminkan perilaku yang tidak baik misalnya baju tidak dimasukan, berambut gondrong, pergaulan bebas,tidak sopan dan sebagainya. Faktor kedua orang tua yang sering memanjakan anak menimbulkan tidak berjalannya pendidikan budi pekerti karena anak yang salah tidak mendapat teguran dari orang tua, faktor ketiga lingkungan pergaulan yang salah, apabila siswa itu bergaul dengan anak yang kurang baik maka secara berlahan siswa itu akan menirukan sikap dan perilaku yang ada pada lingkungannya. Solusi yang dilakukan untuk mengatasi kendala-kendala dalam implementasi pendidikan budi pekerti pada siswa di SMP Negeri 5 Malang adalah yang pertama adalah melakukan pembinaan 
yaitu memberikan pemahaman, pelatihan dan pengawasan kepada siswa merupakan hal yang penting dalam pelaksanaan pendidikan budi pekerti. Kedua guru beserta staf karyawanya memberi contohcontoh perbuatan yang mencerminkan nilai-nilai budi pekerti seperti disiplin, jujur, tanggungjawab, menjaga kerapian, terus keterbukaan, melaksanakan shalat berjamaah. Ketiga menyediakan fasilitasfasilitas sebagai pendukung implementasi pendidikan budi pekerti seperti mushola untuk melakukan ibadah, kantin kejujuran untuk melatih siswa berbuat jujur, tempat sampah untuk meningkatkan sikap kebersihan, tulisan-tulisan atau slogan yang berkaitan dengan budi pekerti agar siswa termotivasi berbuat baik. Keempat mensosialisasikan pendidikan budi pekerti kepada pihak orang tua, agar sekolah dapat mengetahui serta memantau perkembangan sikap dan perilaku anak setiap hari dan saling bertukar informasi dan terbentuk komunikasi yang baik antara orang tua dan pihak sekolah.

\section{DAFTAR PUSTAKA}

Adisusilo, Sutarjo. 2012. Pembelajaran Nilai Karakter. Jakarta: PT RajaGrafindo Persada.

Ahmadi, Abu.1991. Ilmu Pendidikan. Jakarta : PT Rineka Cipta.

Azizy, Qodri. 2003. Pendidikan Untuk Membangun Etika Sosial. Semarang: Aneka Ilmu

Bertens. 1999. Etika Umum. Jakarta: PT Gramedia Pustaka Utama.

Borba, Michele. 2008. Membangun Kecerdasan Moral. Jakarta: PT Gramedia Pustaka Utama

Elmubarok, Zaim. 2008. Membumikan Pendidikan Nilai. Bandung: Alfabeta, CV

Lickona, Thomas. 2013. Educating For Character Mendidik Untuk Membentuk Karakter. Jakarta: PT Bumi Aksara.
Moleong, J Lexi. 2011. Metode penelitian Kualitatif. Bandung : Remaja Rosdakarya.

Muslich, Masnur. 2011. Pendidikan Karakter: Menjawab Tantangan Krisis Multidimensional. Jakarta: Bumi Aksara.

Nurdin, Syarifuddin.2005. Guru Profesional Dan Implementasi Kurikulum. Jakarta: PT Ciputat Press.

Samani, Muchlas dan Hariyanto. 2012. Konsep Dan Model Pendidikan Karakter. Bandung: PT Remaja Rosdakarya.

Santoso, Slamet Imam. 1981. Pembinaan Watak Tugas Utama Pendidikan. Jakarta: UI-Press.

Sjarwi. 2011. Membentuk Kepribadian Anak. Jakarta: PT Bumi Aksara.

Sugiyono. 2010. Metode Penelitian Pendidikan Pendekatan Kuantitatif Kualitatif Dan R\&D. Bandung: Alfabeta

Tilaar, H.A.R. 2002. Pendidikan Kebudayaan Dan Masyarakat Madani Indonesia. Jakarta: PT Remaja Rosdakarya.

Zuriah, Nurul. 2009. Metodologi Penelitian Sosial dan Pendidikan. Malang : Bumi Aksara

Zuriah, Nurul. 2008. Pendidikan Moral \& Budi Pekerti Dalam Perspektif Perubahan. Malang : Bumi Aksara

Widya, Julita. 2013. Pendidikan kewarganegaraan Berfungsi Sebagai Pendidikan Moral. (Online). http:// julita-widya.blogspot.com/2013/03/ pendidikan-kewarganegaraanberfungsi.html diakses 25 Januari 2014

Wijaya, Prima. 2012. Pengertian Implementasi Menurut Nara Sumber. (online). http:// arenakami.blogspot. com/2012/06/implementasi kebijakan- george- edward .html diakses 25 Januari 2014. 